\title{
Corporate Social Responsibility dan Free Cash Flow pada Tax Avoidance
}

\author{
Ni Putu Sintia Sukma Dewi ${ }^{1}$ \\ Fakultas Ekonomi dan Bisnis \\ Universitas Udayana, Indonesia
}

\author{
I Gusti Ayu Made Asri Dwija Putri ${ }^{2}$ \\ Fakultas Ekonomi dan Bisnis \\ Universitas Udayana, Indonesia
}

Surel : sukmadewi588@gmail.com

\section{ABSTRAK}

Tax avoidance adalah usaha wajib pajak untuk mengurangi pembayaran pajak kepada pemerintah yang dilakukan oleh wajib pajak khususnya perusahaan karena tidak melanggar peraturan mengenai perpajakan. Penelitian ini bertujuan untuk menguji pengaruh corporate social responsibility dan free cash flow pada tax avoidance yang diproksikan dengan menggunakan cash effective tax rate (CETR). Penelitian ini dilakukan pada perusahaan manufaktur yang terdaftar di Bursa Efek Indonesia periode 2016-2019. Sampel yang digunakan sebanyak 68 perusahaaan dengan jumlah sampel amatan sebanyak 272 dalam 4 tahun. Teknik analisis data yang digunakan pada penelitian ini adalah analisis regresi linear berganda. Berdasarkan hasil penelitian menunjukkan bahwa corporate social responsibility tidak berpengaruh pada tax avoidance dan free cash flow berpengaruh positif pada tax avoidance.

Kata Kunci: Corporate Social Responsibility; Free Cash Flow; Tax Avoidance.

\section{Corporate Social Responsibility and Free Cash Flow on Tax Avoidance}

\begin{abstract}
Tax avoidance is the taxpayers effort to reduce tax payments to the government made by taxpayers, especially companies because they do not violate regulations regarding taxation. This study aims to examine the effect of corporate social responsibility and free cash flow on tax avoidance which is proxied by using the cash effective tax rate (CETR). This research was conducted at manufacturing companies listed on the Indonesia Stock Exchange for the 2016-2019 period. The sample used was 68 companies with a total observation sample of 272 in 4 years. The data analysis technique used in this study is multiple linear regression analysis. Based on the results of the study show that corporate social responsibility has no effect on tax avoidance and free cash flow has a positive effect on tax avoidance.
\end{abstract}

Keywords: $\quad$ Corporate Social Responsibility; Free Cash Flow; Tax Avoidance.

Artikel dapat diakses : https://ojs.unud.ac.id/index.php/Akuntansi/index

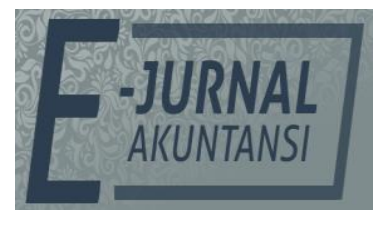

e-ISSN 2302-8556

Vol. 31 No. 5

Denpasar, Mei 2021

Hal. 1069-1081

DOI:

10.24843/EJA.2021.v31.i05.p01

PENGUTIPAN:

Dewi, N.P.S.S, \& Putri, I

G.A.M.A. (2021). Corporate

Social Responsibility dan

Free Cash Flow pada Tax

Avoidance. E-Jurnal

Akuntansi, 31(5), 1069-1081

RIWAYAT ARTIKEL:

Artikel Masuk:

22 Oktober 2020

Artikel Diterima: 19 Februari 2021 


\section{PENDAHULUAN}

Di Indonesia pajak merupakan komponen utama penerimaan negara yang menempati persentase tertinggi dalam APBN (Anggaran Pendapatan dan Belanja Negara) dibandingkan penerimaan negara lainnya. Berdasarkan data APBN yang dipublikasikan oleh Direktorat Jenderal Pajak, besarnya target dan realisasi penerimaan pajak pada Tahun 2016-2019, disajikan dalam Tabel 1, berikut.

Tabel 1. Target dan Realisasi Penerimaan Pajak Indonesia Tahun 2016-2019 (dalam triliun rupiah )

\begin{tabular}{cccc}
\hline Tahun & $\begin{array}{c}\text { Target penerimaan } \\
\text { Pajak }\end{array}$ & $\begin{array}{c}\text { Realisasi Penerimaan } \\
\text { Pajak }\end{array}$ & $\begin{array}{c}\text { Persentase } \\
\text { Penerimaan Pajak }\end{array}$ \\
\hline 2016 & $1.355,20$ & $1.105,73$ & $81,59 \%$ \\
2017 & $1.283,57$ & $1.151,51$ & $89,67 \%$ \\
2018 & $1.424,00$ & $1.315,51$ & $92,23 \%$ \\
2019 & $1.577,56$ & $1.332,06$ & $84,44 \%$ \\
\hline
\end{tabular}

Sumber: Data Penelitian, 2020

Berdasarkan Tabel 1, menunjukkan bahwa komposisi penerimaan pajak dalam APBN tahun 2016-2019 mengalami penurunan. Target penerimaan pajak dalam APBN 2019 sebesar Rp1.577,56 triliun, realisasi penerimaan pajak Rp1.332,06 triliun, yaitu sebesar $84,44 \%$ dari target. Persentase capaian penerimaan pajak tahun 2019 ini menurun dibandingkan dengan capaian periode yang sama di tahun 2018, yaitu sebesar 92,23\%. Hal ini menandakan bahwa belum optimalnya penerimaan pajak sebagai sumber penerimaan negara yang akan digunakan untuk membiayai keperluan negara.

Bagi pemerintah pajak digunakan untuk pembiayaan, pembangunan serta pertumbuhan negara. Sedangkan wajib pajak berusaha menekan beban pajak untuk meminimalkan besarnya pajak yang dibayarkan. Berdasarkan perbedaan kepentingan inilah yang menyebabkan wajib pajak melakukan tindakan penghindaran pajak (tax avoidance). Tax avoidance adalah usaha wajib pajak untuk mengurangi pembayaran pajak kepada pemerintah yang dilakukan oleh wajib pajak khususnya perusahaan karena tidak melanggar peraturan mengenai perpajakan (Hoque M, 2017). Penghindaran pajak ini dapat dikatakan persoalan yang rumit dan unik karena disatu sisi penghindaran pajak diperpolehkan, tetapi di sisi lain hal ini tidak diinginkan (Hanlon \& Heitzman, 2010). Tax avoidance yang dilakukan, dikatakan tidak bertentangan dengan peraturan perundang-undangan perpajakan karena tindakan tax avoidance ini lebih memanfaatkan celah (loopholes) yang terdapat dalam peraturan perpajakan untuk menghindari pembayaran pajak yang jumlahnya lebih besar. Tidak adanya aturan yang dilanggar membuat pemerintah tidak melarang tindakan ini namun tidak dapat dipungkiri bahwa tindakan ini menyebabkan turunnya penerimaan negara (Lestari \& Putri, 2017)

Fenomena penghindaran pajak (tax avoidance) yang terjadi salah satunya dilakukan oleh perusahaan asal Swedia yaitu IKEA. IKEA adalah sebuah perusahaan yang bergerak di sektor peralatan rumah tangga. Namun, diketahui perusahaan ini melakukan upaya penghindaran pajak dengan nilai lebih dari \$1 miliar dalam kurun waktu lima tahun yaitu tahun 2009 sampai tahun 2014. IKEA memindahkan labanya dari negara-negara dengan tarif pajak tinggi ke anak perusahaannya yang berlokasi negara-negara dengan tarif pajak rendah. Selain 
itu, IKEA juga membebankan biaya royalti dari satu perusahaan ke perusahaan lain dalam lingkup kepemilikan yang sama dengan tujuan meminimalisir beban pajak mereka. Pada tahun 2014, IKEA diduga melakukan penghindaran pajak senilai \$39 juta di Jerman, \$26 juta di Prancis, dan \$13 juta di Inggris. Hal ini menyebabkan Uni Eropa mengalami kerugian puluhan miliar dollar per tahunnya (forumpajak.org, 2016).

Corporate Social Responsibility (CSR) adalah tindakan kepedulian yang dilakukan oleh perusahaan sebagai bentuk tanggung jawab sosial dan lingkungan (Carrol \& Buchholtz, 2003). Pajak dan CSR memiliki kemiripan dalam hal keduanya memberikan kontribusi sosial kepada masyarakat (Merkusiwati \& Damayanthi, 2019). Apakah kemiripan ini dipandang sama oleh perusahaan sehingga terdapat pengaruh positif tingkat pengungkapan CSR terhadap pembayaran pajak, atau sebaliknya membuat perusahaan-perusahaan dengan pengungkapan CSR tinggi justru mengurangi beban pajaknya melalui tindakan penghindaran pajak karena menganggap CSR sebagai beban bagi perusahaan. Hoi et al., (2013) mengungkapkan perusahaan dengan kegiatan CSR yang tidak bertanggung jawab lebih agresif dalam menghindari pajak. Penghindaran pajak yang dilakukan oleh perusahaan dianggap sebagai tindakan yang tidak bertanggung jawab secara sosial (socially irresponsible) dan merupakan tindakan yang tidak berlegitimasi (Armstrong et al., 2015).

Penelitian yang dilakukan oleh Hidayati \& Fidiana (2017) menyatakan bahwa pengungkapan CSR memberikan pengaruh positif pada tax avoidance. Berbeda dengan penelitian yang dilakukan oleh Darmayanti \& Merkusiawati, (2019) dan Payanti \& Jati, (2020) menyatakan bahwa pengungkapan CSR tidak berpengaruh pada tax avoidance. Ningrum et al., (2018) menunjukkan hasil bahwa CSR berpengaruh negatif terhadap tax avoidance. Penelitian ini didukung oleh penelitian Lanis \& Richardson (2011) menyatakan bahwa CSR berpengaruh negatif terhadap penghindaran pajak.

Free cash flow (arus kas bebas) merupakan kas lebih suatu perusahaan yang dapat disalurkan oleh manajer kepada kreditor atau pemegang saham yang sudah tidak digunakan untuk operasi atau investasi pada aset tetap (Lidya \& Efendi, 2019). Ogundipe et al., (2012) mengatakan bahwa perusahaan dengan cash flow yang tinggi diperkirakan memiliki jumlah nilai kas yang besar yang berarti bahwa perusahaan memilih pendanaan internal dibandingkan dengan pendanaan eksternal sebagai sumber pendanaannya. Perusahaan memiliki cara dalam mengoptimalkan penggunaan arus kas bebas yang dimiliki salah satunya dengan melakukan penghindaran pajak. Penghindaran pajak dilakukan dengan mengatur besarnya pajak yang dikenakan dari laba yang diperoleh perusahaan untuk menutupi tindakan manajer yang tidak optimal dalam memanfaatkan kas yang tersedia secara tepat yang hanya menguntungkan dirinya sendiri.

Penelitian yang dilakukan Kim \& Im (2017) mengatakan bahwa arus kas operasi berpengaruh terhadap tax avoidance. Kurniawan \& Nuryanah (2017) mengatakan bahwa penghindaran pajak tidak memiliki pengaruh signifikan terhadap kepemilikan kas tunai. Tambunan \& Septiani (2017) mengatakan bahwa penghindaran pajak berpengurh negatif dan signifikan terhadap cash holding perusahaan. Namun berbeda dengan penelitian yang dilakukan Khuong et al., (2019) menyatakan bahwa penghindaran pajak memiliki hubungan positif dan 
signifikan dengan kepemilikan kas dari perusahaan-perusahaan yang terdaftar di Vietnam.

Penelitian tentang tax avoidance dan faktor-faktor yang mempengaruhinya semakin menarik untuk diteliti, karena fenomena pajak selalu mengalami perkembangan terutama di Indonesia sehingga diperlukan informasi-informasi dan studi-studi terbaru mengenai kondisi pajak dari waktu ke waktu. Penelitian ini memiliki kebaruan yaitu penggunaan variabel free cash flow yang diprediksi mempengaruhi tax avoidance relatif sedikit digunakan dalam penelitian sebelumnya.

Teori keagenan merupakan teori yang menjelaskan adanya konflik kepentingan dalam sebuah perusahaan. Menurut Jensen \& Meckling (1976) teori keagenan adalah hubungan antara satu pihak atau lebih (principal) memperkerjakan orang lain (agent) untuk memberikan suatu jasa dan kemudian mendelegasikan wewenang pengembalian keputusan kepada agen tersebut. Sementara itu menurut Eisenhardt (1989) teori keagenan dilandasi oleh tiga asumsi sifat manusia yaitu : (1) asumsi tentang sifat manusia pada umumnya memiliki sifat untuk mementingkan diri sendiri (self interest), (2) manusia memiliki daya pikir terbatas mengenai persepsi masa mendatang (bounded rationality), dan (3) manusia selalu menghindari risiko (risk adverse). Perbedaan kepentingan antara agen dan prinsipal muncul akibat asumsi sifat dasar manusia yang mementingan diri sendiri. Konflik keagenan muncul apabila tujuan yang ingin dicapai oleh manajer perusahaan tidak sejalan dengan kepentingan pemegang saham (Nariastiti \& Ratnadi, 2014). Hal tersebut memicu timbulnya ketidakseimbangan informasi antara principal dan agen yang disebut sebagai asimetri informasi. Adanya asimetri informasi akan mendorong agen untuk menyembunyikan beberapa informasi yang tidak diketahui prinsipal dengan tujuan untuk memaksimalkan keuntungan pribadi.

Dowling \& Pfeffer (1975) menjelaskan bahwa dalam teori legitimasi organisasi berusaha menciptakan keselarasan antara nilai-nilai sosial yang ada pada kegiatan organisasi dengan norma-norma yang ada pada lingkungan sosial dimana organisasi tersebut merupakan bagian dalam lingkungan sosial tersebut. Teori legitimasi memfokuskan pada interaksi antara masyarakat, pemerintah, individu, dan kelompok masyarakat. Hidayati \& Murni (2009) menyatakan bahwa bagi perusahaan legitimasi dari masyarakat dapat diperoleh jika perusahaan melakukan tanggung jawab sosial masyarakat atau sering disebut sebagai Corporate Social Responsibility (CSR). Perusahaan dapat bertanggung jawab sosial kepada masyarakat melalui pemerintah dengan cara membayar beban pajak sesuai ketentuan yang berlaku dan tidak melakukan tindakan tax avoidance. Landolf (2006) menyatakan penghindaran pajak perusahaan merupakan salah satu tindakan yang tidak bertanggung jawab sosial oleh perusahaan karena penghindaran pajak tidak sesuai dengan prinsip CSR yang dilakukan perusahaan dalam upaya untuk mendapatkan legitimasi dari masyarakat.

Corporate social responsibility merupakan bentuk tanggung jawab perusahaan kepada semua stakeholdernya baik dari pemerintah, investor, kreditor, konsumen maupun masyarakat sekitar. Kewajiban membayar pajak merupakan salah satu bentuk tanggung jawab sosial dan lingkungan perusahaan. 
Perusahaan yang terlibat penghindaran pajak adalah perusahaan yang tidak bertanggung jawab sosial (Lanis \& Richardson, 2013).

Penelitian Dharma \& Noviari (2017) dan Ningrum et al., (2018) menunjukkan bahwa CSR berpengaruh negatif terhadap tax avoidance. Perusahaan yang memiliki tingkat aktivitas CSR yang tinggi menunjukkan bahwa perusahaan memiliki rasa tanggung jawab sosial yang tinggi termasuk tanggungjawabnya dalam membayar pajak sesuai peraturan yang berlaku, yang menunjukkan perusahaan tersebut memiliki praktik tax avoidance yang rendah. Berdasarkan uraian, maka dapat dibuat hipotesis penelitian sebagai berikut.

$\mathrm{H}_{1}$ : Corporate social responsibility berpengaruh negatif pada tax avoidance.

Free cash flow adalah arus kas yang benar-benar tersedia untuk dibayarkan kepada seluruh investor setelah perusahaan membayar semua kewajiban dan melakukan investasi (Habib, 2008). Free cash flow sangat mudah dikendalikan oleh manajer sehingga memotivasi manajer dalam menggunakannya untuk kepentingan pribadi. Dalam konteks teori agensi, penghindaran pajak adalah perilaku opportunistic yang dilakukan manajer untuk keuntungan mereka sendiri. Untuk menutupi perilaku opportunistic ini, manajer mencoba untuk membatasi beberapa informasi spesifik perusahaan (Kim et al., 2011).

Khuong et al., (2019) menyatakan penghindaran pajak memiliki hubungan positif yang signifikan dengan kepemilikan kas dari perusahaan yang terdaftar di Vietnam. Perusahaan memiliki cadangan kas yang besar lebih mampu bersaing dan mendominasi pasar. Akibatnya, manajer seringkali menerapkan penghindaran pajak untuk mengurangi pengeluaran pajak mereka dengan tujuan meningkatkan daya saing mereka. Semakin tinggi tingkat arus kas bebas yang dimiliki perusahaan menyebabkan manajer berperilaku opportunistic untuk mengurangi jumlah pajak yang harus dibayar maka manajer melakukan tindakan tax avoidance. Berdasarkan uraian, maka dapat dibuat hipotesis penelitian sebagai berikut.

$\mathrm{H}_{2}$ : Free cash flow berpengaruh positif pada tax avoidance.

\section{METODE PENELITIAN}

Penelitian ini dilakukan pada perusahaan manufaktur yang terdaftar di Bursa Efek Indonesia (BEI) dengan melakukan akses pada situs www.idx.co.id. Objek yang menjadi kajian dalam penelitian ini adalah Corporate Social Responsibility, Free Cash Flow dan Tax Avoidance yang diproksikan melalui rasio-rasio keuangan perusahan manufaktur yang terdaftar di Bursa Efek Indonesia periode 2016-2019.

Populasi dalam penelitian ini adalah perusahaan manufaktur yang terdaftar di Bursa Efek Indonesia yang berjumlah sebanyak 170 perusahaan. Sampel pada penelitian ini adalah 272 perusahaan manufaktur yang terdaftar di Bursa Efek Indonesia (BEI) periode 2016-2019 yang dipilih dengan menggunakan metode nonprobability sampling dengan teknik purposive sampling di Bursa Efek Indonesia (BEI) periode 2015-2018.

Tax avoidance merupakan suatu cara untuk menekan beban pajak yang ditanggung perusahaan secara legal yang tidak melanggar peraturan perpajakan karena dalam peraturan perpajakan diperbolehkan adanya tax avoidance. Pengukuran tax avoidance dalam penelitian ini dihitung melalui Cash Effective Tax 
Rate (CETR). CETR adalah jumlah kas yang dibayarkan oleh perusahaan untuk membayar pajak terhadap laba sebelum pajak yang dihasilkan oleh perusahaan (Budiman \& Setiyono, 2012). CETR baik digunakan untuk memprediksi adanya tindakan tax avoidance yang dilakukan perusahaan. CETR tidak berpengaruh terhadap perubahan estimasi seperti perlindungan pajak. Nilai CETR yang rendah menunjukkan bahwa tingkat tax avoidance yang tinggi, sebaliknya nilai CETR yang tinggi menunjukkan tingkat tax avoidance yang rendah. CETR dapat dihitung menggunakan rumus sebagai berikut.

CETR $=\frac{\text { Pembayaran } \text { Pajak }_{\text {Laba sebelum pajak }}}{\text { Corpote }}$ Social

Corporate Social Responsibility merupakan tindakan yang dilakukan oleh perusahaan sebagai bentuk tanggungjawab sosial dan lingkungan yang tujuannya mendapatkan reputasi baik dimata masyarakat dengan melakukan kegiatan yang sesuai dengan norma serta kebutuhan masyarakat. Pengukuran variabel corporate social responsibility dilakukan dengan menggunakan acuan pada indikator Global Reporting Initiative (GRI) versi 4.0 yang berjumlah 91 item. Adapun pengukurannya dengan rumus sebagai berikut.

CSRDI $=\frac{\sum x i, j}{n j}$

Keterangan :

CSRDI : Indeks pengungkapan tanggung jawab sosial perusahaan

$\Sigma X \mathrm{i}, \mathrm{j} \quad:(1=$ jika item i diungkapkan, $0=$ jika item i tidak diungkapkan $)$

nj $\quad$ : Jumlah item untuk perusahaan $\mathrm{j}, \mathrm{nj} \leq 91$

Menurut Rosdini (2009) free cash flow adalah aliran kas yang masih tersisa dari aktivitas pembiayaan semua proyek yang menghasilkan net present value (NPV) positif yang dipergunakan untuk mendanai berbagai keperluan proyek yang sudah direncanakan. Menurut Kieso et al., (2012: 219) Arus kas bebas (free cash flow) dapat diukur menggunakan dengan rumus sebagai berikut.

Free Cash Flow $=$ Kas bersih dari aktivitas operasi $-\mathrm{PM}$ - dividen

Keterangan :

PM : Pengeluaran Modal

Teknik analisis data yang digunakan pada penelitian ini adalah regresi linier berganda. Analisis regresi linier berganda (multiple linier regression) dapat menunjukkan arah hubungan antar variabel, digunakan untuk memecahkan rumusan masalah yang ada, atau apakah memiliki hubungan positif atau negatif yang diproses dengan menggunakan program Statisical Package For Social Science (SPSS). Persamaan regresi linier berganda dapat dinyatakan sebagai berikut.

$Y=\alpha+\beta_{1} X_{1}+\beta_{2} X_{2}+\varepsilon$

Keterangan :

Y : Tax Avoidance

a $\quad$ : Nilai Konstanta

$\beta_{1}, \beta_{2}$ : Koefisien regresi variabel $X_{1}$ dan $X_{2}$

$\mathrm{X}_{1}$ : Corporate social responsibility

$\mathrm{X}_{2} \quad$ : Free cash flow

$\varepsilon \quad:$ Error 


\section{HASIL DAN PEMBAHASAN}

Statistik deskriptif dalam penelitian ini memberikan gambaran mengenai data yang tersaji seperti nilai minimum, nilai maksimum, nilai rata- rata (mean) dan standar deviasi. Uji statistik deskriptif masing-masing variabel dalam penelitian ini dapat dilihat dalam Tabel 2, berikut.

Tabel 2. Hasil Uji Statistik Deskriptif

\begin{tabular}{lllccl}
\hline & $\mathrm{N}$ & Minimum & Maximum & Mean & Std. Deviation \\
\hline $\begin{array}{l}\text { Corporate Social } \\
\text { Responsibility }\end{array}$ & 272 & 0,604 & 0,890 & 0,751 & 0,045 \\
$\begin{array}{l}\text { Free Cash Flow } \\
\text { Tax Avoidance }\end{array}$ & 272 & $-1,402$ & 861,866 & 5,307 & 190,512 \\
& 272 & 0,025 & 17,810 & 0,436 & 1,144
\end{tabular}

Sumber: Data Penelitian, 2020

Pada Tabel 2, Menunjukkan bahwa data variabel corporate social responsibility berjumlah 272 dengan nilai minimum sebesar 0,0604 oleh PT. Akasha Wira International Tbk (ADES) pada tahun 2016 dan nilai maksimum sebesar 0,890 oleh PT. Unilever Indonesia Tbk (UNVR) pada tahun 2019. Corporate social responsibility memiliki rata-rata sebesar 0,751 dan standar deviasi corporate social responsibility sebesar 0,045 . Hal ini berarti adanya penyimpangan data terhadap nilai rata- ratanya sebesar 0,751 dan nilai penyimpangan data corporate social responsibility tersebut lebih kecil dari nilai rata-ratanya, maka sebaran data corporate social responsibility cukup dekat.

Data variabel free cash flow berjumlah 272 dengan nilai minimum sebesar 1.402.677.054.499 oleh PT. Mayora Indah Tbk (MYOR) pada tahun 2018 dan nilai maksimum sebesar 861.866.409.643 oleh PT. Fajar Surya Wisesa Tbk (FASW) pada tahun 2016. Variabel free cash flow memiliki rata-rata sebesar 5.307.682.230,41. Nilai standar deviasi free cash flow sebesar 190.512.444.320,891. Hal ini berarti adanya penyimpangan data terhadap nilai rata-ratanya sebesar 5.307.682.230,41 dan nilai penyimpangan data free cash flow tersebut lebih besar dari nilai rata-ratanya, maka sebaran data free cash flow cukup jauh.

Data tax avoidance berjumlah 272 dengan nilai minimum sebesar 0,025 oleh PT. Pan Brothers (PBRX) pada tahun 2019 dan nilai maksimum sebesar 17,810 oleh PT. Malindo Feedmill Tbk (MAIN) pada tahun 2017. Tax avoidance memiliki rata-rata sebesar 0,436 dan nilai standar deviasi tax avoidance sebesar 1,144. Hal ini berarti adanya penyimpangan data terhadap nilai rata-ratanya sebesar 0,436 dan nilai penyimpangan data tax avoidance tersebut lebih besar dari nilai rata-ratanya, maka sebaran data tax avoidance cukup jauh.

Analisis regresi linier berganda dalam penelitian ini dilakukan untuk mengetahui adanya pengaruh antar variabel dan digunakan untuk memecahkan rumusan masalah yang ada, atau apakah memiliki pengaruh positif atau negatif. Agar hasil analisis Best Linier Unbiased Estimator (BLUE), maka perlu dilakukan uji asumsi klasik. Uji asumsi klasik yang dilakukan dalam penelitian ini sebagai berikut.

Uji normalitas ini bertujuan untuk mengetahui apakah residual dari model regresi yang dibuat berdistribusi normal atau tidak. Data yang baik adalah data yang berdistribusi normal. Pengujian normalitas data dilakukan dengan menggunakan Kolmogorov-Smirnov (K-S) dengan melihat sig (2-tailed). Apabila sig (2-tailed) lebih besar dari level of significant $(\alpha=0.05)$ maka data 
berdistribusi normal, sedangkan apabila sig (2-tailed) lebih kecil dari level of significant $(\alpha=0.05)$ maka data berdistribusi tidak normal. Hasil pengujian uji normalitas dapat dilihat pada Tabel 3, berikut.

Tabel 3. Hasil Uji Normalitas

\begin{tabular}{lll}
\hline & & Unstandardized Residual \\
\hline $\mathrm{N}$ & Mean & 272 \\
Normal Parameters & Std. Deviation & 0,000 \\
& Absolute & 0,180 \\
Most Extreme Differences & Positif & 0,125 \\
& Negatif & $-0,560$ \\
& & 0,125 \\
Kolmogorov-Smirnov Z & & 0,660 \\
Asymp. Sig. (2-tailed) &
\end{tabular}

Sumber: Data Penelitian, 2020

Berdasarkan Tabel 3, dapat dilihat bahwa nilai Kolmogorov-Smirnov sebesar 0,125 dan nilai signifikansi Asymp. Sig. (2-tailed) sebesar 0,660. Oleh karena nilai signifikansi uji Kolmogorov-Smirnov lebih besar dari 0,05 maka model regresi tersebut berdistribusi normal.

Uji multikolinearitas bertujuan untuk menguji apakah dalam model regresi ditemukan adanya korelasi antar variabel independen. Model regresi yang baik seharusnya tidak mengandung korelasi diantara variabel independennya. Uji multikolinearitas dilakukan dengan melihat nilai tolerance lebih dari 0,10 dan Variance Inflation Faktor (VIF) kurang dari 10. Apabila nilai tolerance dibawah 0,10 atau nilai VIF diatas 10, maka terjadi multikolinearitas. Hasil pengujian multikolinearitas dapat dilihat pada Tabel 4, berikut.

Tabel 4. Hasil Uji Multikolinearitas

\begin{tabular}{llc}
\hline & \multicolumn{2}{c}{ Collinearity Statistics } \\
\cline { 2 - 3 } & Tolerance & VIF \\
\hline (Constant) & & \\
Corporate Social Responsibility & 0,92 & 1,146 \\
Free Cash Flow & 0,92 & 1,146 \\
\hline
\end{tabular}

Sumber: Data Penelitian, 2020

Berdasarkan Berdasarkan Tabel 4, menunjukkan bahwa nilai tolerance dari variabel bebas yaitu corporate social responsibility dan free cash flow lebih dari 0,10 dan VIF dari variabel-variabel tersebut kurang dari 10. Hal ini menunjukkan bahwa model regresi tersebut terbebas dari multikoliniearitas.

Uji heteroskedastisitas dilakukan untuk mengetahui apakah dalam model regresi terdapat ketidaksamaan varians dari residual satu pengamatan ke pengamatan lainnya. Model regresi yang baik adalah model regresi yang tidak mangandung gejala heteroskedastisitas. Jika nilai signifikansi dari variabel bebas lebih besar dari 0,05 maka model regresi tidak mengandung heteroskedastisitas. Hasil pengujian heteroskedastisitas dapat dilihat pada Tabel 5, berikut.

Tabel 5. Hasil Uji Heteroskedastisitas

\begin{tabular}{lll}
\hline & T & Sig. \\
\hline (Constant) & 9,087 & 0,000 \\
Corporate Social Responsibility & $-1,591$ & 0,113 \\
Free Cash Flow & 2,245 & 0,126 \\
\hline
\end{tabular}

Sumber: Data Penelitian, 2020 
Berdasarkan Tabel 5, dapat dilihat bahwa nilai signifikansi dari variabel bebas yaitu corporate social responsibility dan free cash flow masing-masing lebih besar dari 0,05 . Hal ini menunjukkan bahwa model regresi tersebut terbebas dari gejala heteroskedastisitas.

Model regresi yang baik adalah model regresi yang bebas dari autokolerasi dengan melihat nilai Durbin-Watson $(\mathrm{dw})$ yang diperoleh dari nilai $\mathrm{dl}=1,793$ dan $\mathrm{du}=1,807$, sehingga 4 - $\mathrm{dl}=2,207$ dan 4 -du $=2,193$. Hasil uji autokorelasinya adalah du $<\mathrm{d}<4$-du yaitu 1,793 $<1,807<2,193$, maka dapat disimpulkan bahwa data tersebut tidak terdapat autokorelasi. Hasil analisis regresi linier berganda dapat dilihat pada Tabel 6, berikut.

Tabel 6. Hasil Analisis Regresi Linier Berganda

\begin{tabular}{|c|c|c|c|c|c|}
\hline & \multicolumn{2}{|c|}{ Unstandardized Coefficients } & \multirow{2}{*}{$\begin{array}{l}\text { Standardized } \\
\text { Coefficients } \\
\text { Beta }\end{array}$} & \multirow[b]{2}{*}{$\mathrm{t}$} & \multirow[b]{2}{*}{ sig. } \\
\hline & B & Std.Error & & & \\
\hline (Constant) & 0,285 & 0,023 & & 12,213 & 0,000 \\
\hline $\begin{array}{l}\text { Corporate Social } \\
\text { Responsibility }\end{array}$ & $-0,035$ & 0,101 & $-0,021$ & $-0,345$ & 0,730 \\
\hline Free Cash Flow & 8,065 & 0,000 & 0,222 & 3,728 & 0,000 \\
\hline R Square & 0,049 & & & & \\
\hline $\begin{array}{l}\text { Adjusted R } \\
\text { Square }\end{array}$ & 0,042 & & & & \\
\hline F Statistik & 6,994 & & & & \\
\hline Signifikansi & 0,001 & & & & \\
\hline
\end{tabular}

Sumber: Data Penelitian, 2020

Berdasarkan Tabel 6, diperoleh suatu persamaan regresi sebagai berikut. $\mathrm{Y}=0,285-0,035 \mathrm{X}_{1}+8,065 \mathrm{X}_{2}$

Nilai konstanta (a) 0,285 menunjukkan bahwa apabila corporate social responsibility $\left(\mathrm{X}_{1}\right)$ dan free cash flow $\left(\mathrm{X}_{2}\right)$ sama dengan nol, maka nilai CETR $(\mathrm{Y})$ adalah sebesar 0,285 . Nilai koefisien $\beta 1=-0,035$ menunjukkan bahwa jika nilai corporate social responsibility $\left(\mathrm{X}_{1}\right)$ naik 1 persen, maka nilai CETR $(\mathrm{Y})$ akan turun sebesar 3,5 persen dengan asumsi variabel lainnya konstan. Nilai koefisien $\beta 2=$ 8,065 menunjukkan bahwa jika nilai free cash flow $\left(\mathrm{X}_{2}\right)$ naik 1 persen, maka nilai CETR (Y) akan naik sebesar 806,5 persen dengan asumsi variabel lainnya konstan.

Uji koefisien determinasi $\left(\mathrm{R}^{2}\right)$ dilakukan untuk mengukur seberapa jauh kemampuan variansi variabel independen dalam menerangkan variansi variabel dependen. Nilai koefisien determinasi adalah antara nol dan satu. Berdasarkan Tabel 7. dapat dilihat bahwa nilai Adjusted $R$ Square pada model sebesar 0,042. Nilai Adjusted $R$ Square pada tabel artinya variabel tax avoidance dapat dijelaskan oleh variabel corporate social responsibility dan free cash flow sebesar 4,2 persen, sedangkan sisanya sebesar 95,8 persen dijelaskan oleh variabel lain di luar model.

Uji F bertujuan untuk menilai kelayakan model dalam penelitian ini dan mengetahui apakah semua variabel independen dalam model regresi mempunyai pengaruh terhadap variabel dependen. Cara untuk melihat uji $\mathrm{F}$ ini dengan melihat nilai signifikansi dari model regresi. Dikatakan lolos uji $\mathrm{F}$ apabila nilai signifikansi $<0,05$ jadi jika model regresi memiliki nilai signifikansi $<0,05$ 
maka model regresi tersebut layak digunakan sebagai penelitian. Berdasarkan Tabel 7, dapat dilihat bahwa pada model memiliki Sig. sebesar 0,001 lebih kecil dari $\alpha=0,05$, menunjukkan model penelitian ini layak untuk digunakan sebagai alat analisis untuk menguji pengaruh variabel independen terhadap variabel dependen. Hal ini berarti bahwa variabel corporate social responsibility dan free cash flow berpengaruh secara bersama-sama terhadap variabel dependennya yaitu tax avoidance.

Hipotesis pertama $\left(\mathrm{H}_{1}\right)$ menyatakan bahwa corporate social responsibility berpengaruh negatif pada tax avoidance. Hasil analisis menunjukkan bahwa koefisien regresi bernilai negatif sebesar 0,035 . Hal tersebut berarti corporate social responsibility menunjukkan arah negatif dengan tax avoidance. Nilai signifikansi (p-value) untuk variabel corporate social responsibility sebesar 0,730 yaitu lebih besar dari 0,05. Hal ini menunjukkan corporate social responsibility tidak berpengaruh pada tax avoidance. Hipotesis pertama yang menyatakan corporate social responsibility berpengaruh negatif pada tax avoidance ditolak.

Berdasarkan hasil penelitian ini, corporate social responsibility tidak berpengaruh pada tax avoidance, artinya besar kecilnya pengungkapan CSR yang dilakukan oleh perusahaan tidak mempengaruhi perusahaan dalam melakukan tax avoidance. Hasil Penelitian ini sesuai dengan hasil penelitian dari Darmayanti \& Merkusiawati (2019), Dewi (2020), dan Payanti \& Jati (2020) yang menyatakan bahwa CSR tidak berpengaruh pada penghindaran pajak. Informasi CSR yang diungkapkan oleh perusahaan belum tentu sesuai dengan kondisi yang sebenarnya. Sehingga tingkat pengungkapan CSR yang dilaporkan dalam laporan tahunan tidak bisa dijadikan jaminan rendahnya tindakan tax avoidance yang dilakukan perusahaan.

Hipotesis pertama $\left(\mathrm{H}_{2}\right)$ menyatakan bahwa free cash flow berpengaruh positif pada tax avoidance. Hasil analisis menunjukkan bahwa koefisien regresi bernilai positif sebesar 8,065. Hal tersebut berarti free cash flow menunjukkan arah positif dengan tax avoidance. Nilai signifikansi (p-value) untuk variabel free cash flow sebesar 0,000 yaitu lebih kecil dari 0,05. Hal ini menunjukkan free cash flow berpengaruh pada tax avoidance. Hipotesis pertama yang menyatakan free cash flow berpengaruh positif pada tax avoidance diterima.

Berdasarkan hasil penelitian ini menunjukkan bahwa free cash flow berpengaruh positif pada tax avoidance. Penelitian yang dilakukan Khuong et al., (2019) menyatakan penghindaran pajak memiliki hubungan positif yang signifikan dengan kepemilikan kas dari perusahaan yang terdaftar di Vietnam. Perusahaan memiliki cadangan kas yang besar lebih mampu bersaing dan mendominasi pasar. Akibatnya, manajer seringkali menerapkan penghindaran pajak untuk mengurangi pengeluaran pajak dengan tujuan meningkatkan daya saing. semakin besar jumlah arus kas bebas maka semakin tinggi fleksibilitas keuangan yang dimiliki perusahaan yang membuat manajer semakin berperilaku oportunistik yang dapat mengurangi laba perusahaan sehingga perusahaan cenderung melakukan tindakan pengindaran pajak.

\section{SIMPULAN}

Berdasarkan hasil analisis data dan pembahasan yang telah diuraikan, maka dapat ditarik simpulan bahwa Coroporate social responsibility tidak berpengaruh 
pada tax avoidance. Hal ini berarti besar kecilnya pengungkapan corporate social responsibility yang dilakukan oleh perusahaan tidak mempengaruhi tindakan perusahaan dalam melakukan tax avoidance. Free cash flow berpengaruh positif pada tax avoidance. Hal ini berarti semakin besar jumlah free cash flow yang dimiliki perusahaan maka semakin meningkatkan tindakan tax avoidance.

Peneliti menyarankan bagi investor dalam melakukan investasi di perusahaan, investor dapat memastikan bahwa penghindaran pajak yang dilakukan oleh perusahaan merupakan aktivitas yang dilakukan karena pengaruh pilihan strategi bisnisnya bukan merupakan tindakan oportunistik yang dapat memberikan dampak negatif terhadap reputasi perusahaan. Bagi emiten, penelitian ini dapat dijadikan referensi untuk patuh membayar pajak sesuai peraturan yang berlaku dan mempertimbangkan keputusan untuk melakukan tindakan tax avoidance agar terhindar dari sanksi perpajakan dan menurunkan pandangan positif yang telah diterima perusahaan. Bagi penelitian selanjutnya disarankankan menggunakan sektor lain seperti pertambangan, perbankan dan lain-lain. Hasil penelitian ini menunjukkan bahwa variabel CSR tidak berpengaruh pada tax avoidance. Penelitian selanjutnya disarankan untuk meneliti faktor lain yang berperan dalam hubungan CSR pada tax avoidance dan dapat menambahkan variabel pemoderasi.

\section{REFERENSI}

Armstrong, C. S., Blouin, J. L., Jagolinzer, A. D., \& Larcker, D. F. (2015). Corporate governance, incentives, and tax avoidance. Journal of Accounting and Economics, 60(1), 1-17. https:// doi.org/10.1016/j.jacceco.2015.02.003

Budiman, J., \& Setiyono. (2012). Pengaruh Karakter Eksekutif terhadap Penghindaran Pajak (Tax Avoidance). Proceeding Simposium Nasional Akuntansi XV Banjaemasin.

Carrol, A. B., \& Buchholtz, A. K. (2003). Business \& Society Ethics and Stakeholder Management Sixth Edition.

Darmayanti, P. P. B., \& Merkusiawati, N. K. L. A. (2019). Pengaruh Ukuran Perusahaan, Profitabilitas, Koneksi Politik dan Pengungkapan Corporate Social Responsibility Pada Tax Avoidance. E-Jurnal Akuntansi, 26(3), 1992-2019. https://doi.org/10.24843/ eja.2019.v26.i03.p12

Dewi, N. N. (2020). Pengaruh Corporate Social Responsibility, Ukuran Perusahaan Dan Kepemilikan Institusional Terhadap Penghindaran Pajak ( Studi Empiris pada Perusahan Manufaktur Sub Sektor Makanan dan Minuman yang Listing di BEI pada tahun 2014-2018). Universitas Islam Indonesia.

Dharma, N. B. S., \& Noviari, N. (2017). Pengaruh Corporate Social Responsibility Dan Capital Intensity Terhadap Tax Avoidance. E-Jurnal Akuntansi, 18(1), 529556.

Dowling, J., \& Pfeffer, J. (1975). Organizational Legitimacy: Social Values and Organizational Behavior. The Pacific Sociological Review, 18(1), 122-136.

Eisenhardt, K. M. (1989). Agency Theory: An Assessment and Review. In Academy of Management Review (Vol. 14, Nomor 1, hal. 57-74).

Forum Pajak. (2016). IKEA Terjerat Kasus Penghindaran Pajak. Forum Pajak Indonesia. $\quad$ https:// forumpajak.org/ikea-terjerat-kasuspenghindaranpajakIndonesia. 
Habib, A. (2008). The role of accruals and cash flows in explaining security returns: Evidence from New Zealand. Journal of International Accounting, Auditing and Taxation, 17(1), 51-66. https:// doi.org/10.1016/j.intaccaudtax.2008.01.003

Hanlon, M., \& Heitzman, S. (2010). A review of tax research. Journal of Accounting and Economics, 50(2-3), 127-178. https://doi.org/10.1016/j.jacceco.2010.09.002

Hidayati, N., \& Fidiana. (2017). Pengaruh Corporate Social Responsibility dan Good Corporate Governance terhadap Pengindaran Pajak. Jurnal Ilmu dan Riset Akuntansi, 6(3), 1053-1070. https://doi.org/10.1016/j.ajic.2016.04.226

Hidayati, N. N., \& Murni, S. (2009). Pengaruh Pengungkapan Corporate Social Responsibility Terhadap Earningss Response Coefficient Pada Perusahaan High Profile. Jurnal Bisnis dan Akuntansi, 11(1), 1 - 18.

Hoi, C. K., Wu, Q., \& Zhang, H. (2013). Is Corporate Social Responsibility (CSR) Associated with Tax Avoidance? Evidence from Irresponsible CSR Activities. Journal of International Accounting Research. https://doi.org/10.2308/accr-50982

Hoque M, K. (2017). International Tax Avoidance and Tax Havens. Journal International of Cost and Management, 45(1), 63-67.

Jensen, M. C., \& Meckling, W. H. (1976). Theory Of The Firm: Managerial Behavior, Agency Costs And Ownership Structure. Journal of Financial Economics 3, 305-360. https:/ / doi.org/10.1177/0018726718812602

Khuong, N. V., Thai Ha, N. T., Hoang Minh, M. T., \& Thu, P. A. (2019). Does corporate tax avoidance explain cash holdings? The case of Vietnam. Economics and Sociology, 12(2), 79-93. https://doi.org/10.14254/2071789X.2019/12-2/5

Kieso, D. E., Weygandt, J. J., \& Warfield, T. D. (2012). Akuntansi Intermediate, Edisi 12 Jilid 1. In Jakarta: Erlangga.

Kim, J. B., Li, Y., \& Zhang, L. (2011). Corporate tax avoidance and stock price crash risk: Firm-level analysis. Journal of Financial Economics, 100(3), 639-662. https://doi.org/10.1016/j.jfineco.2010.07.007

Kim, J. H., \& Im, C. C. (2017). The study on the effect and determinants of smalland medium-sized entities conducting tax avoidance. Journal of Applied Business Research, 33(2), 375-390. https:/ / doi.org/10.19030/jabr.v33i2.9911

Kurniawan, M. I., \& Nuryanah, S. (2017). The effect of corporate tax avoidance on the level of corporate cash holdings: Evidence from indonesian public listed companies. Australasian Accounting, Business and Finance Journal, 11(4), 38-52. https:// doi.org/10.14453/aabfj.v11i4.4

Landolf. (2006). Tax and Corporate Responsibility. International Tax review.

Lanis, R., \& Richardson, G. (2011). The effect of board of director composition on corporate tax aggressiveness. Journal of Accounting and Public Policy, 30(2011), 50-70. https://doi.org/10.1016/j.jaccpubpol.2010.09.003

Lanis, R., \& Richardson, G. (2013). Corporate social responsibility and tax aggressiveness: A test of legitimacy theory. Accounting, Auditing and Accountability Journal, 26(1), 75-100. https://doi.org/10.1108/09513571311285621

Lestari, G. A. W., \& Putri, I. G. A. M. A. D. (2017). Pengaruh Corporate Governance, 
Koneksi Politik, Dan Leverage Terhadap Penghindaran Pajak. E-Jurnal Akuntansi, 18(3), 2028-2054.

Lidya, K., \& Efendi, D. (2019). Pengaruh perencanaan pajak, kepemilikan manajerial dan free cash flow terhadap nilai perusahaan. Jurnal Ilmu dan Riset Akuntansi, 8(7), 1-16.

Merkusiwati, N. K. L. A., \& Damayanthi, I. G. A. E. (2019). Pengaruh Pengungkapan CSR, Karakter Eksekutif, Profitabilitas, Dan Investasi Aktiva Tetap Terhadap Penghindaran Pajak. E-Jurnal Akuntansi, 29(2), 833-853. https://doi.org/10.24843/eja.2019.v29.i02.p26

Nariastiti, N. W., \& Ratnadi, N. M. D. (2014). Pengaruh Asimetri Informasi, Corporate Governance Dan Ukuran Perusahaan Pada Manajemen Laba. EJurnal Akuntansi, 9(3), 717-727.

Ningrum, A. K., Suprapti, E., \& Hidayat Anwar, A. S. (2018). Pengaruh Pengungkapan Corporate Social Responsibility Terhadap Tax Avoidance Dengan Gender Sebagai Variabel Moderasi (Studi Empiris Pada Perusahaan Manufaktur Yang Terdaftar Di Bursa Efek Indonesia Tahun 2016). Economic, Business, Management and Accounting Journal, 15(01). https://doi.org/10.30651/blc.v15i01.1260

Ogundipe, L. O., Ogundipe, S. E., \& Ajao, S. K. (2012). Cash Holding and Firm Characteristics: Evidence From Nigerian Emerging Market. Journal of Business Economics and Finance, 1(2), 45-58.

Payanti, N. M. D., \& Jati, I. K. (2020). Pengaruh Pengungkapan Corporate Social Responsibility, Good Corporate Governance dan Sales Growth pada Tax Avoidance. E-Jurnal Akuntansi Udayana, 30(5), 1066-1083.

Rosdini, D. (2009). Pengaruh Free Cash Flow terhadap Dividend Policy. Working Paper in Accounting and Finance, 1-17. https:// doi.org/10.1149/1.3581024

Tambunan, D. N., \& Septiani. (2017). Pengaruh Penghindaran Pajak Terhadap Cash Holding Perusahaan Dengan Leverage Dan Return on Asset (Roa) Sebagai Variabel Moderasi. 6(4), 1-12. 